\title{
CAN ALGAL BIOTECHNOLOGY BRING EFFECTIVE SOLUTION FOR CLOSING THE PHOSPHORUS CYCLE? USE OF ALGAE FOR NUTRIENT REMOVAL - REVIEW OF PAST TRENDS AND FUTURE PERSPECTIVES IN THE CONTEXT OF NUTRIENT RECOVERY
}

\author{
KATĚ̌INA SUKAČOVÁ* and JAN ČERVENÝ
}

Global Change Research Institute, Academy of Sciences of the Czech Republic, Bělidla 986/4a, Brno 603 00, Czech Republic

*Corresponding author: sukacova.k@czechglobe.cz

\begin{abstract}
Eutrophication of water by nutrient pollution is a global environmental issue. Biological methods for removing nutrients are environmentally friendly and sustainable. Therefore, this article summarizes main trends in the use of algae for removing nutrients from wastewater using both suspended and attached algal-based systems. A wide variety of algal species and experimental approaches has been tested to date. Researchers report that algae are able to effectively remove a variety of pollutants and nutrients. This review also discusses the potential of algal-based technology for nutrient, especially phosphorus, recovery. Despite the fact that effective nutrient removal has been demonstrated, there are still many challenges to be overcome in the development of succesfull technologies.
\end{abstract}

Keywords: wastewater treatment, algae, nutrients removal, phosphorus recovery

\section{Introduction}

Pollution of surface water due to high concentrations of nutrients is a global issue affecting all countries worldwide. Eutrophication is a term, which was used in limnology already at the beginning of the 20th century (Weber 1907). But this term was used only for describing the effects of pollution on ecosystems without a deeper understanding of the causes. Since the mid-20th century, mass presence of algal blooms in reservoirs, growth of macrophyta and periodic killing of fish were symptoms, which were not possible to ignore (Schindler 2006). R. A. Vollenweider was the first scientist who linked high nutrient input into lakes with eutrophication. He performed a comprehensive analysis of available data and of systematic scientific studies. From the results, he deduced that a reduction in the input of phosphorus $(\mathrm{P})$ and in some cases also nitrogen $(\mathrm{N})$ would avoid eutrophication and its symptoms in lakes (Vollenweider 1968). Vollenweider's results were supported by W. T. Edmonson, who published a six-year study of Lake Washington. He found a strong correlation between $\mathrm{P}$ concentrations and algal standing crops. When the nutrient load was reduced by diverting sewage away from the lake, it rapidly recovered (Edmonson 1970). In other studies $P$ was also determined as the limiting factor for growth of phototrophic organisms in lakes and reservoirs (e.g. Schindler 1977; Ahlgren 1978; Holtan 1981). Numerous studies focused on causes and effects of high nutrient concentrations on water ecosystems were carried out starting from seventies of 20th century (e.g. Hutchinson 1973; Ahlgren 1978; Howarth 1988; Jeppesen et al. 2002).

The high input of $\mathrm{P}$ and $\mathrm{N}$ into surface water originated from variety of sources (Smith 1998). Main point sources of nutrient pollution are mostly wastewater efflu- ent (municipal and industrial), runoff and leachate from waste disposal sites, runoff and infiltration from animal feedlots, runoff from mines and unsewered industrial sites and overflows of combined storm and sanitary sewers (Novotny and Olem 1994). Point sources are more easily monitored than nonpoint sources, which are diffuse. Nonpoint sources of nutrients include runoff from agriculture, runoff from unsewered areas, septic tank leachate and runoff from failed septic systems and atmospheric deposition over water surfaces (Carpenter et al. 1998). High concentration of $\mathrm{P}$ and $\mathrm{N}$ in water results in an abundant growth of algae, cyanobacteria and macrophytes. Nutrient pollution also causes shifts in the dominant species towards cyanobacteria, which are potential producers of toxic compounds (Skulberg et al. 1984). The abundant growth of algal biomass starts a cascade of negative processes in water ecosystems. Dense algal mats reduce the quality of the living conditions for other organisms such as invertebrates and fish. Decomposition of large amounts of algal biomass causes diel fluctuations in $\mathrm{pH}$ and in dissolved oxygen concentrations, which is harmful for fish. Decomposition of biomass can also cause taste and odour problems. Worse water quality also results in restrictions on recreation and swimming in polluted water (Quinn 1991).

Monitoring and control of nutrient load is an essential part of water management (Daniel et al. 1994; EU Water Frame Directive 2000/60/EU). The problem of nutrient pressures on water resources are also included in the 7th Environment Action Programme (Decision No 1386/2013/EU of the European Parliament, 2013). Despite all efforts, control of nutrient pollution remains one of the most important environmental issues (Jarvie et al. 2013).

The next serious topic inseparably connected with eutrophication, is the $\mathrm{P}$ recycling. $\mathrm{P}$ is an essential ele- 
ment for all living organisms. P rocks are mined only in a few regions in the world. The currently known reserves are concentrated in few countries, particularly Morocco (Scholz et al. 2013). The resources of $P$ rocks are very small in Europe, especially bearing in mind the high demand. The study "Phosphorus flows and balances of the European Union Member States" describe an unbalanced economy in terms of P. On the one hand European countries are fully dependent on imports of $\mathrm{P}$ rock, on the other hand there are a great losses of $\mathrm{P}$ to wastewater and food waste (van Dijk et al. 2016). Big losses of imported $P$ to the environment cause serious environmental problems. This unsustainable management of non-renewable resources needs to be changed. For the above reasons, it is necessary to focus on the development of new technologies for phosphorus removal and recovery.

Biological methods of nutrient removal from wastewater are considered to be low cost and environmental-friendly technologies (Mantzavinos et al. 2005). Different groups of microorganisms can be used for removing nutrients (Bashan and Bashan 2004). Many studies demonstrate the high ability of microalgae to reduce the nutrient content of wastewater (Christenson and Sims 2011; Whitton et al. 2015). Moreover, this method can bring several benefits because it does not generate additional waste, such as activated sludge, does not require the use chemical substances for phosphorus reduction and provides an opportunity for efficiently recovering nutrients (Mantzavinos et al. 2005; Pittman et al. 2011). Therefore, the objectives of the present study are to summarize past development and recent progress in nutrient removal technologies using microalgae in the context of nutrient recovery.

\section{The Algae and their Role in Biotechnology}

The cyanobacteria and algae are highly heterogeneous groups of organisms including both small unicellular species and large freshwater and marine organisms of siz-

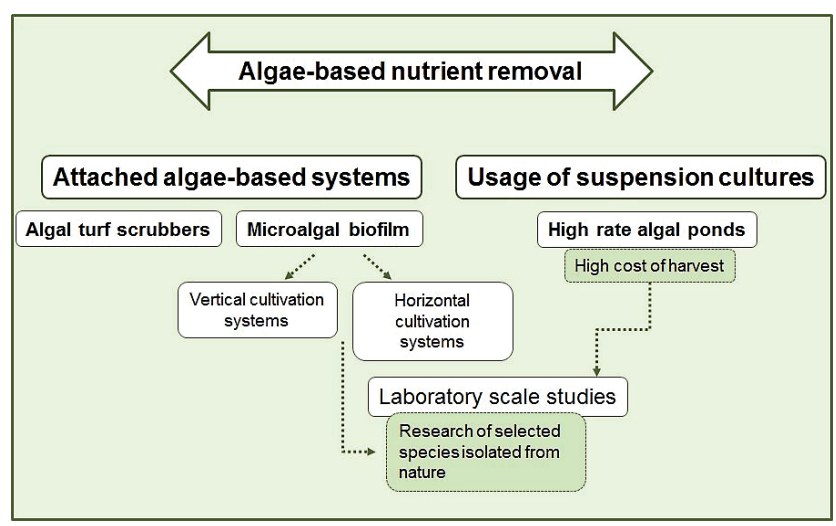

Fig. 1 Summary of main trends in nutrient removal technologies using algae. es more than $1 \mathrm{~m}$ with a multicellular organization. The algae, like plants, are photosynthetic organisms but have a simpler cellular organization. The algae have no roots, stems, leaves or complex vascular networks. They occur as single cells, multicellular colonies, simple or branched filamentous, leafy or blade forms without a high degree of cell differentiation (Barsanti and Gualtieri 2006). The cyanobacteria and algae can colonize all biotopes. They can live as planktonic organisms in the euphotic zone of lakes, water reservoirs or in the sea. They also colonize firm surfaces submerged in water and live attached on sediments, stones, plants etc. (Stevenson 1996). Microscopic species are called "microalgae". Large species with complex cellular organization are called "macroalgae". The term "microalgae" is used in a wide sense in applied phycology. It includes both prokaryotic cyanobacteria and eukaryotic algae (Masojídek and Prášil 2010).

Algae are used in several areas of biotechnology. Primarily, it is the commercial production of microalgae for dietary supplements, cosmetic products and nutrition for aquaculture (Becker 2004). Microalgae are characterized by a high content of valuable compounds such as proteins, amino acids, essential unsaturated fatty acids and vitamins. Commercially produced genera are mainly Chlorella, Arthrospira (Spirulina), Dunaliella, Nannochloropsis and Haematococcus (Spolaore et al. 2006; Mimouni et al. 2012).

Microalgae were identified as an important source of lipids with potential use as feedstock for biofuel production. Microalgae can produce different types of lipids, for example unsaturated fatty acids (eicosapentanoic acid or docosahexanoic acid) and neutral lipids including triacylglycerids (Markou and Nerantzis 2013). They can be a suitable feedstock for biofuel production after conversion of the lipids to fatty acid methyl esters.

Research on the potential for using algae for bioremediation is currently an important issue in microalgal biotechnology. Microalgae can be used in wastewater treatment for the removal of different pollutants. Reduction in chemical and biological oxygen demands are mainly studied together with the removal of $\mathrm{N}$ and $\mathrm{P}$ in agricultural, domestic or municipal wastewater (e.g. Shelef et al. 1980; Fallowfield and Garret 1985; Arcila and Buitrón 2016). Algae are also an effective bio-sorbent for removing heavy metals because their cell surfaces are negatively charged and they have large cell surface to volume ratios (Filip and Peters 1979; Wilde and Benemann 1993; Roberts et al. 2013; Li et al. 2015).

As mentioned above, many studies have shown the ability of algae to grow in wastewater and to reduce nutrient concentrations in laboratory-scale studies (e.g. Proulx et al. 1993; Chevalier et al. 2000; Doria et al. 2012). For this purposes, the microalgae can be cultivated in suspension or attached to a firm surface. Much attention has been paid to the cultivation of algae in wastewater treatment ponds and natural attached algal-based systems (Adey et al. 2011; Park et al. 2011). The possibility 
of nutrient removal coupled with production of biofuels has been studied. The connection of these two processes would bring important economic benefits, including a reduction in the cost producing biofuels (Chinnasamy et al. 2010; Christenson and Sims 2011).

\section{Wastewater Treatment Using Suspended Algae}

\section{Wastewater Treatment of High Rate Algal Ponds (WWT HRAP)}

The first studies that focused on the potential of algae for wastewater treatment were published in the middle of the 20th century (Oswald and Gotaas 1957; Bogan et al. 1961). At that time, the concept of WWT HRAP was established. High rate algal ponds (HRAP) are shallow oxidation ponds mixed by means of a paddle wheel. They are used for the treatment of municipal, industrial and agricultural wastewater (Park et al. 2011). This technology was tested in South Africa in the 70s. Its efficiency in treating industrial wastewater with high concentrations of $\mathrm{N}$ was studied over a long period of time. Parameters of HRAP were optimized to achieve better light conditions in cultivation suspension and to minimize evaporation of water from the HRAP. Density of cell culture was set at $0.5 \mathrm{~g} \mathrm{DW}^{1-1}$. Simultaneously, a sufficient reduction in nitrogenous substances was achieved (Bossman and Hendricks 1980). HRAP was tested for different kinds of wastewater, but the most often investigated treatment of liquid wastes was those from agriculture. Repeated reductions in $\mathrm{BOD}$, concentrations of $\mathrm{N}$ and $\mathrm{P}$ are recorded in agriculture wastewater (Shelef et al. 1980; Picot et al. 1991). Reduction of $\mathrm{N}$ substances in municipal wastewater was studied in Spain. During a pilot study, algal cultures in HRAP was able to remove about $70 \%$ of the N (Garcia et al. 2000). Predictive models of algal growth, oxygen production and reduction in pollutants were developed based on long-term studies (Kroon et al. 1989; Sukenik et al. 1991). Typical biomass production in these systems ranged from $8-35 \mathrm{~g} \mathrm{~m}^{-2} \mathrm{~d}^{-1}$ (Shelef et al. 1980).

No special algal species were selected for inoculating HRAP, instead the algal assemblage developed naturally in the ponds. Therefore, many studies were focused on the ecology and succession of these specific algal assemblages. Palmer (1974) studied species composition in WWT HRAP. He found that the most frequently recorded species were green algae, especially Chlorella, Ankistrodesmus, Scenedesmus, Chlamydomonas, Micractinium, Euglena and Cyanobacteria, genus Oscillatoria. Erganshev and Tajiev (1986) report similar species in six lagoons in central Asia. Sim and Goh (1988) also report an algal assemblage dominated by green algae in HRAP containing agriculture wastewater in Singapore.

The main disadvantage of HRAP is that it is difficult and expensive to harvest the algal biomass, which is necessary for effective wastewater treatment (Cromar et al. 1992). HRAP is mostly criticized because of their low productivity due to light limitation, high dissolved oxygen levels and loss of biomass to grazers (Chisti 2007; Mata et al. 2010; Park et al. 2011). Recently, researchers have focused on optimizing the operating parameters such as hydraulic retention time, mixing, $\mathrm{CO}_{2}$ availability and cultivation mode and controlling grazers (Park and Craggs 2011; Park et al. 2013). New progress was recently presented in the potential usage of WWT HRAP for lowcost biofuel production (Mehrabadi et al. 2015; Arcila and Buitrón 2016).

\section{Laboratory-Scale Studies Using Suspension Cultures}

While HRAP are naturally colonized by algal assemblages, many studies since the 90s have evaluated the effectiveness of particular species of algae for $\mathrm{N}$ and $\mathrm{P}$ removal. In particular, great attention was paid to those species that were easy to harvest in order to reduce the costs of harvesting. Proulx et al. (1993) studied the growth of the cyanobacterium Phormidium bohneri in secondary effluent. These species are able to remove $83 \%$ of the $\mathrm{N}$ and $81 \%$ of the $\mathrm{P}$ from municipal wastewater, moreover, they also have a high ability to aggregate and settle in ponds. Several evaluations of the nutrient removal capacity under different conditions for several benthic cyanobacteria are published. Arctic species Phormidium tenue and Oscillatoria sp. were tested to develop technology suitable for the cool climate in Canada (Talbot and de la Noüe 1993; Chevalier et al. 2000).

Doria et al. (2012) isolated the microalga Scenedesmus acutus from municipal wastewater and recorded its biomass production coupled with reduction in nutrients during growth in a tubular bioreactor (50 1). She reports a biomass production of $0.24 \mathrm{~g} \mathrm{DW}^{-1} \mathrm{~d}^{-1}$ and complete removal of $\mathrm{N}$ from wastewater. The disadvantage was that it was necessary to add microelements (Fe, $\mathrm{Mg}$ ) to the wastewater. Different species of green microalgae are repeatedly used in various types of wastewater. The genus Scenedesmus is able to remove $94 \%$ of organic N and $66 \%$ of P from municipal wastewater (de Alva et al. 2013). Similarly, Ren et al. (2015) report that Scenedesmus isolated from soil reduced the concentration of COD and nutrients in starch wastewater. Other species used are for example Monoraphidium sp., Chlorella ellipsoidea, Chlorella vulgaris, Neochloris oleoabundans or Desmodesmus $s p$. All these species are able to effectively remove nutrients from wastewater (Wang et al. 2011; Arbib et al. 2014; Holbrook et al. 2014; Fang et al. 2015).

In addition to monocultures, algal consortia were also tested. Chinnasamy et al. (2010) developed algal consortia and determined their capacity for nutrient absorption. A consortium including the green microalgae Chlorella sp., Chlamydomonas sp., Scenedesmus sp., Gloeocystis $s p$. and cyanobacteria Anabaena $s p$. and Limnothrix sp. was cultivated in wastewater mainly from carpet mills. This consortium removed $96 \%$ of the nutrients. Similarly, 
Renuka et al. (2013) used four consortia dominated by Chlorella sp., Scenedesmus sp., Chlorococcum sp. and cyanobacteria Phormidium sp., Limnothrix sp. and Anabaena $s p$. and report that the highest nutrient removal was achieved by a consortium dominated by filamentous cyanobacteria. Generally, algal consortia are able to survive environmental fluctuations and are resistent to invasion by other species (Subashchandrabose et al. 2011).

Recently, the research on the use of algae for wastewater treatment has included an evaluation of the energy content of the algal biomass produced, lipid production and production of biofuels (Fang et al. 2015; Kim et al. 2015; Ren et al. 2015). This topic is also connected with the development of new technologies and new devices for cultivating algae.

\section{Wastewater Treatment Using Attached Algae-based Systems}

The harvest of algal biomass from suspension in wastewater is technically difficult and accounts for $20-30 \%$ of the costs connected with cultivating algae (Liu and $\mathrm{Vy}$ verman 2015). This led to a greater interest in solutions using algae attached to submerged surfaces (Hoffmann 1998).

Attached algal communities are traditionally called "periphyton", a term that was introduced for the first time in 1928 (Sládečková 1962). Later, the names "phytobentos" or "microphytobenthos" were adopted by hydrobiologists. Over the last few decades, the term "algal biofilm" for attached algae has become more widely accepted in algal biotechnology (Wetzel 2001). Research on periphyton was conducted intensively from 60 s. Special interest was particularly directed to studies on the community structure and primary productivity in streams and rivers. Artificial shallow channels were also used for research on nutritional conditions (e.g. McIntire 1968). The effect of high concentrations of $\mathrm{P}$ and $\mathrm{N}$ on the primary productivity of algae is reported in many publications (e.g. Whitford and Schumacher 1961; Lowe et al. 1986; Davison 1991; McCormick 1996). As one of the first, Bush et al. (1963) report using algae attached in a raceway pond for removing nutrients. Hemens and Mason (1968) evaluate wastewater tertiary treatment in an outdoor shallow stream. Sládečková et al. (1983) proposed using artificial streams fitted with nylon mesh to remove nutrients from polluted water. Vymazal et al. (1988) further continued this concept and tested periphyton growth and rate of nutrient uptake in an outdoor artificial channel $(5 \mathrm{~m}$ long) with artificial substrates for algal growth. The algal assemblage that developed spontaneously on the substrata came from the upper part of stream, which served as a source of water for the channel. In both experiments there were reductions in the concentrations of phosphorus and nitrogen together with an abundance of algal growth.

\section{The Algal Turf Scrubbers (ATS) - Ecologically Engineered, Algal Based System}

Simultaneously with Czech researchers, the American scientist Walter Adey and co-workers examined options for improving the artificial channel concept (Adey et al. 1993). They were inspired by coral reefs. The algal turfs growing on coral reefs are characterized by high primary production due to regular flooding by waves. Scientists designed pulsing hydraulic system to mimic the wave action on coral reefs (Adey et al. 2011). This ATS system consisted of an attached algal community in the form of a "turf" growing on polyethylene screens. The algal turfs grew in a shallow slopping raceway into which water was pumped from a water body. After the biological uptake of nutrients by algae, the water was released at the end of the raceway back into the water body. The algal biomass was regularly harvested (Craggs et al. 1996). The algal assemblage on turfs consisted mostly of filamentous green algae Spirogyra sp., Microspora sp., Ulothrix sp., Rhizoclonium sp. and Oedogonium sp. These dominant species were accompanied by the cyanobacteria Phormidium $s p$. and Oscillatoria sp. and benthic diatoms. These algal turfs are a heterogeneous community with a high growth rate and high ability of regenerating (Craggs et al. 1996; Mulbry et al. 2008; Sandefur et al. 2011). Maximum values of the rate of $\mathrm{P}$ and $\mathrm{N}$ uptake were 0.73 and $1.58 \mathrm{~g} \mathrm{~m}^{-2} \mathrm{~d}^{-1}$ respectively. Harvests (including trapped organic particulates) varied from 5 to $60 \mathrm{~g} \mathrm{DW} \mathrm{m}^{-2} \mathrm{~d}^{-1}$ (Craggs et al. 1996; Mulbry et al. 2008; Kangas and Mulbry 2014).

This ecologically engineered, algal-based technology has been developed for more than 30 years in USA and was patented as an Algal Turf Scrubber (ATS ${ }^{\mathrm{TM}}$ ). The nutrient reduction potential of ATS systems have been assessed for both point and non-point sources of pollution. For example, the treatment of dairy manure effluent in central Maryland (USA) and agricultural wastewater in the Florida Everglades (Adey et al. 2011). Commercialization of this technology is under active development by HydroMentia Inc., which builds and operates ATS mainly in Florida. Recently, research to improve the performance of ATS has continued, with tests involving new applications and evaluations of the harvested biomass (Adey et al. 2011; Valeta and Verdegem 2015).

\section{The Algal Biofilms}

The ATS technology is an ecologically engineered design of a controlled ecosystem for nutrient removal. The success of this technology has depended mainly on the construction of hydraulic system with a specific water regime (Adey et al. 2011). But the assemblage of periphytic organisms was not manipulated to favour more desirable species with a higher ability to remove nutrients. A novel approach is to use microalgal biofilms consisting of selected species. These species are selected based on 
a high ability to reduce nutrients (Sukačová et al. 2015). This approach is a shift from ecological engineering to the design of biotechnology applications.

The term microalgal biofilm was introduced for microalgal assemblages that consist of microalgae that colonize illuminated surfaces submerged in water (Jarvie et al. 2002). The use of term microalgal biofilm overlaps with name periphyton in hydrobiology as described above. In aquatic ecosystems, the growth of microalgal biofilms starts with the colonization of a submerged surface by pioneer species. At first, the surface is colonized by diatoms, which are followed by coccal green microalgae. The growth of filamentous microalgae and cyanobacteria after one month is the last phase of species succession (McIntire 1968; Komárek and Sukačová 2004). Development of microalgal biofilms depend mainly on water temperature and trophic conditions (Johnson et al. 1997). The growth of algal biomass is exponential at the beginning and then decreases depending on the thickness of the biofilm. Biomass losses are caused by respiration, cell death, parasitism and grazing by invertebrates (Biggs 1996). In watercourses, the algal biofilm plays a key role in biogeochemical cycles and transformation of carbon, N and P (Allan and Castillo 2007).

In the context of algal biotechnology, the research on algal biofilms is motivated by two factors. The first is the cultivation of biotechnologically important species in the form of a biofilm in order to reduce the cost of harvesting the biomass. The evaluation of the potential of algal biofilms for nutrient removal is the second reason. The research is closely connected with the design of different cultivation devices. The microalgal biofilm cultivation systems can be constructed as panels from different materials placed vertically or horizontally with a slight slope.

The vertically constructed system "Twin Layer" bioreactor using filter paper attached to a glass plate as the area for biofilm growth. Cultivation medium flows down the glass plate and keeps the filter paper moist. This system is placed in an aquarium and is aerated with air enriched with $\mathrm{CO}_{2}$. Production potential of such a bioreactor ranges from 3 to $18 \mathrm{~g} \mathrm{DW} \mathrm{m}^{-2} \mathrm{~d}^{-1}$ depending on the intensity of illumination (Liu et al. 2013). A similar system was used for nutrient removal from municipal wastewater. Hallochlorella rubescens CCAC 0126 growing on a nylon membrane fixed to a metallic frame was situated vertically and wastewater from different treatment stages flowed down the membrane. The average uptake rate of $\mathrm{PO}_{4}-\mathrm{P}$ varied from 0.8 to $1.5 \mathrm{mg} \mathrm{l}^{-1} \mathrm{~d}^{-1}$, the removal of $\mathrm{P}$ from wastewater during a two-day cycle of bioreactor operation was $78.9 \%$ and $85 \%$, respectively, and the average microalgal growth was $6.3 \mathrm{~g} \mathrm{DW} \mathrm{m}^{-2} \mathrm{~d}^{-1}$ (Shi et al. 2014).

Other carrier materials used for biofilm cultivation are radially flexible PVC fillers placed in plexiglass chambers. Biofilm consisted of a mixture of several species: Chlorella pyrenoidosa, Scenedesmus obliquus, Anabaena flos-aquae, Synechococcus elongatus and Microcystis aeruginosa. $\mathrm{P}$ and $\mathrm{N}$ removal efficiency was about 95\% and $84 \%$, respectively from simulated wastewater during a four-day cycle.

Guzzon et al. (2008) focus on basic research on P removal using biofilms. The growth was measured in a horizontal incubator with four separated lanes under different conditions (Zippel et al. 2007). Polycarbonate slides inside lanes served as cultivation areas. Guzzon and co-workers describe the influence of different parameters such as light intensity, temperature and flow rate on biofilm growth and $\mathrm{P}$ removal. They report positive correlations between algal biomass production and its $\mathrm{P}$ content with light intensity. They also describe the occurrence of polyphosphate granules inside the cells of the algae on the biofilms.

In several studies, polystyrene foam was found to be a suitable material for algal biofilm cultivation. Johnson and Wen (2010) determined the growth of Chlorella sp. attached to polystyrene foam in dairy manure wastewater and evaluated the algal biomass for producing biodiesel. This revealed that this technology potentially can provide a less expensive method of growing and harvesting algal production. Posadas et al. (2013) constructed a horizontal cultivation system with polystyrene foam as the carrier material for the biofilm, which was inoculated with a microalgal-bacterial assemblage from HRAP treated municipal wastewater. They compared the removal efficiency of N, P and organic compounds by the microalgal biofilm with that of a bacterial biofilm in the same cultivation system. The microalgal biofilm was the most effective in nutrient removal and the reduction of organic compounds was the same in both systems.

The comprehensive research on new wastewater treatment technologies using microalgal biofilm was done in the European center of excellence for sustainable technology (WETSUS) in the Netherlands. Boelee et al. (2011) determined whether microalgal biofilms were suitable for the post-treatment of municipal wastewater. Reduction in $\mathrm{P}$ and $\mathrm{N}$ was measured in a laboratory-scale system. Microalgal biofilm dominated by filamentous cyanobacteria (Phormidium and Pseudanabaena) and coccal green algae (Scenedesmus sp.) were cultivated on PVC plastic sheets. Wastewater circulated over the biofilm, which absorbed nutrients. Maximum rate of $\mathrm{P}$ and $\mathrm{N}$ uptake under continuous illumination was $0.13 \mathrm{~g} \mathrm{~m}^{-2} \mathrm{~d}^{-1}$ and $1 \mathrm{~g} \mathrm{~m}^{-2} \mathrm{~d}^{-1}$, respectively. Subsequent studies of Boelee and co-workers focused on the evaluation of the frequency of harvesting in relation to biomass production and nutrient reduction. They report that the same biomass was harvested on the second, fourth and seventh day. The premise of this study that there would be a reduction in the biomass produced as the biofilm thickened was not confirmed (Boelee et al. 2014).

The work mentioned above was done in a laboratory. There are very few pilot studies that evaluate removal efficiency of biofilms. Sukačová et al. (2015) report the rate of uptake of $\mathrm{P}$ by an algal biofilm assemblage that 


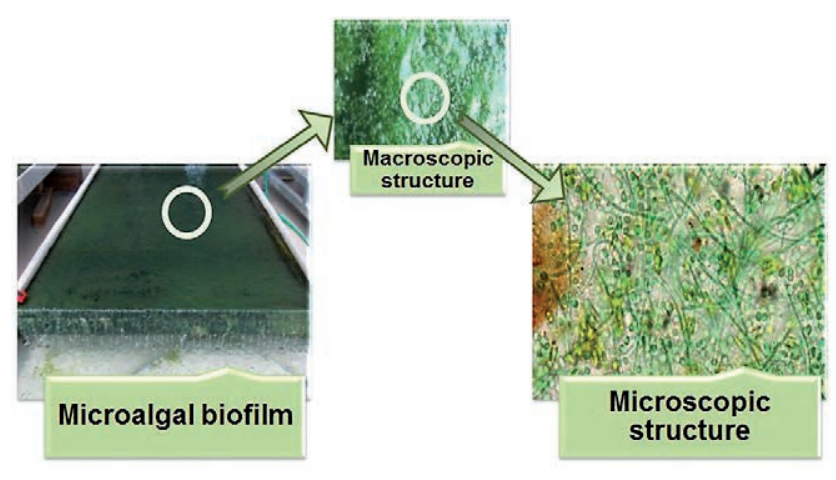

Fig. 2 Macroscopic and microscopic structure of algal biofilm. The filamentous cyanobacteria form a net that traps unicellular green algae.

consisted of filamentous cyanobacteria and coccal green algae, which grew on concrete panels with total area of $8 \mathrm{~m}^{2}$ inclined at a slight angle. The wastewater was retained within the system for 24 hours. The average rate of uptake of $\mathrm{P}$ was about $0.16 \mathrm{~g} \mathrm{~m}^{-2} \mathrm{~d}^{-1}$. The algal biofilm removed about $97 \%$ of total $\mathrm{P}$ from municipal wastewater after 24 hours.

The studies cited indicate that algal biofilms are very efficient at removing nutrients. Compared with ATS, the use of phototrophic biofilms on a large-scale is still uncommon and needs further improvement before it can be used for treating wastewater (Kesaano and Sims 2014; Whitton et al. 2015).

\section{Matrix-Immobilized Algae}

There are several laboratory studies on phycoremediation technologies using immobilized algae (e.g. Lau et al. 1997; de Bashan et al. 2002; Zhang et al. 2008). The main advantages of this technique is the separation of microalgae from wastewater and the production of a usable biomass. The immobilization method involves encapsulation of microalgae in beads. The material used for the immobilization must be very permeable, of low toxicity and highly transparent. The most often used material is alginate (Lau et al. 1997; Zhang et al. 2008). Various strains of microalgae have been immobilized, including the green algae Chlorella vulgaris, C. pyrenoidosa, C. sorokiniana, Scenedesmus bicellularis, $S$. quadricauda and cyanoprocaryota Phormidium (De la Noüe and Proulx 1988; Kaya and Picard 1996; Filippino et al. 2015). Immobilized microalgae are highly efficient at removing nitrogen and phosphorus from secondary effluents (De la Noüe and Proulx 1988; Kaya and Picard 1996). However, over the last few decades there has been little attention given to developing algal immobilization techniques for the treatment of tertiary wastewater (Filippino et al. 2015). Recently, research has started to focus on the optimization of growth of immobilized algae and increasing the efficiency of nutrient removal in the laboratory (Filippino et al. 2015).

\section{Nutrient Recovery Potential}

Considering the future need to recover nutrients, the utilization of nutrients by microalgae is an important issue in the nutrient removal process. The algal biomass that develops in wastewater can be utilised in several ways (Pittman et al. 2011). However, the presence of heavy metals, micropollutants or pathogens can reduce the possibility of reusing the nutrients.

One option is to use the algal biomass as a biofertilizers. The use of blue green algae for soil conditioning and as a biofertilizer in rice production is reported (Metting et al. 1990; Metting 1996). Mulbry et al. (2005) have used the algal biomass that developed during the treatment of cow manure treatment as a slow release fertilizer. They compared seedling growth using a commercial potting soil amended with either ATS biomass or a roughly comparable commercial fertilizer and report that plant growth was similar in both. Roberts et al. (2015) report that algae growing in bioremediation ponds at a coalfired power station sequester metals from the wastewater. The algal biomass, which consists of the filamentous alga Oedogonium, can be converted to algal biochar for soil amelioration. When this biochar is added to a low-quality soil, it improves its retention of nutrients from fertilizer, which resulted in a better growth of radishes of 35-40\% (Roberts et al. 2015). Although biochar is currently used to improve soil by restoring the carbon pool and providing essential trace elements, we hypothesize that algal biomass rich in phosphorus can also be effectively converted to biochar for enriching soils with phosphorus.

Algae are a good supplementary feed for livestock because they have a high protein content (Spolaore et al. 2006). However, the potential for using algae produced during wastewater treatment for feeding animals has not yet been studied. The algal biomass would have to meet the standards required for animal feed, which means that the feed source has to be free of pathogens and harmful substances.

Nutrient recovery using the algal biomass from wastewater treatment presents many challenges that remain to be overcome. Many algal species have been successfully used for removing nutrients in laboratory cultivation systems (e.g. Chinnasamy et al. 2010; Johnson and Wen 2010; Boelee et al. 2011; Fang et al. 2015), however, there are very few large-scale applications (Craggs et al. 1996). The lack of large-scale systems is limiting research on its potential for producing a phosphorus rich algal biomass. One of the few studies on the production of algal biomass as a biofertlizer is still that of Mulbry et al. (2005), which was published more than ten years ago. However, the results of this research indicates that algal biomass produced during the treatment of wastewater has very high potential for use as a biofertilizer. 


\section{Conclusions}

The recovery of nutrients, especially $\mathrm{P}$, seems to be necessary for the sustainable development of agriculture and the environment in the future. Many studies demonstrate the high ability of algae to remove nutrients from wastewater. Fewer studies have also shown the high potential of algae for nutrient recycling. Several steps are needed to overcome the problem of successfully developing algal biotechnologies for nutrient recycling. Primarily, it is the optimization of current technologies for more efficient sequestration of nutrients. These efforts should be focused especially on the traditional usage of HRAP for wastewater treatment. The adaptation of new methods developed in the laboratory for large scale use is also important. This step includes selection of suitable cultivation systems for specific species with a high ability of nutrient removal. The large-scale cultivation of microalgae in wastewater using closed photobioreactors is rarely reported. However, the optimization of energy inputs into the cultivation process and new technologies for harvesting could bring progress in this area. The next stage of the research will be the utilization of nutrient rich algal biomass obtained during the wastewater treatment process. The application of different kinds of biomass to soil connected with the investigation of nutrient release and the utilization by plants are only a few of the issues, but they are very complex. An effective solution could close the nutrient cycle. Despite the high potential of microalgae for nutrient recovery, there is still little attention paid to their use for nutrient removal in water management.

\section{Acknowledgements}

This work was supported by the Ministry of Education, Youth and Sports of CR within the National Sustainability Program I (NPU I), grant number LO1415.

\section{REFERENCES}

Adey WH, Luckett C, Jensen K (1993) Phosphorus removal from natural waters using controlled algal production. Restor Ecol 1: 29-39.

Adey WH, Loveland K (2007) Dynamic Aquaria: Building and Restoring Living Ecosystems. Academic Press/Elsevier.

Adey WH, Kangas PC, Mulbry W (2011) Algal Turf Scrubbing: Cleaning surface waters with solar energy while producing a biofuel. Bioscience 61: 434-441.

Ahlgren I (1978) Response of Lake Norrvikken to reduced nutrient loading. Verh Int Ver Limnol 20: 846-850.

Allan JD, Castillo MM (2007) Stream Ecology: Second Addition. Springer, The Netherlands.

Andersen RA (2005) Algal culturing techniques. Academic Press. USA, pp 1-596.

Arbir Z, Ruiz J, Álvarez-Díaz P, Garrido-Pérez C, Perales JA (2014) Capability of different microalgae species for phytoremediation processes: Wastewater tertiary treatment, $\mathrm{CO}_{2}$ bio-fixation and low cost biofuels production. Water Research 49: 465-474.

Arcila JS, Buitrón G (2016) Microalgae-bacteria aggregates: effect of the hydraulic retention time on the municipal wastewater treatment, biomass settleability and methane potential. J Chem Technol Biotechnol 91: 2862-2870.

Barsanti L, Gualtieri P (2006) Algae: Anatomy, Biochemistry and Biotechnology. Taylor and Francis Group, USA, pp 1-289.

De Bashan LE, Moreno M, Hernandez JP, Bashan Y (2002) Removal of ammonium and phosphorus ions from synthetic wastewater by the microalgae Chlorella vulgaris coimmobilized in alginate beads with the microalgae growth-promoting bacterium Azospirillum brasiliense. Water Research 36: 2941-2948.

Bastian RK, Reed SC (1979) Aquaculture systems for wastewater treatment. Seminar Proc Ang Engin Assesment. US EPA, Washington DC, 20460.

Becker W (2004) Microalgae in human and animal nutrition. Richmond A (ed) Handbook of Microalgal Culture: Biotechnology and Aplied Phycology. Wiley-Blackwell Publishing, USA, pp 312-351.

Biggs BJF (1996) Patterns in benthic algae of streams In: Stevenson RJ, Bothwell ML, Lowe RL (eds) Algal Ecology: Freshwater Benthic Ecosystems. Academic Press Elsevier, pp 31-56.

Boelee NC, Temmink H, Janssen M, Buisman CJN, Wijffels RH (2011) Nitrogen and phosphorus removal from municipal wastewater effluent using microalgal biofilms. Water Research 45: 5925-5933.

Boelee NC, Temmink H, Janssen M, Buisman CJN, Wijffels RH (2012). Scenario analysis of nutrient removal from municipal wastewater by microalgal biofilms. Water 4: 460-473.

Boelee NC, Janssen M, Temmink H, Shrestha R, Buisman CJN, Wijffels RH (2014) Nutrient removal and biomass production in an outdoor pilot-scale phototrophic biofilm reactor for effluent polishing. Appl Biochem Biotechnol 172: 405-422.

Bogan RH, Albertson OE, Pluntze JC (1961) Use of algae in removing phosphorus from sewage. Trans Am Soc Civil Eng 126: 231-250.

Bosman J, Hendricks F (1980) The development of an algal pond system for the removal of nitrogen from an inorganic industrial effluent. Proc Int Symp On Aquaculture in Wastewater NIWP, CSIR, Pretoria, pp 26-35.

Bush AF, Isherwood JD, Rodgi S (1963) Dissolved solids removal from wastewater by algae. Trans Am Soc Civil Eng 128: 84-102.

Callow ME (2000) Algal biofilms. In: Evans LV (ed) Biofilms: Recent advances in their study and control, Harwood Academic Publishers, Amsterdam Netherlands, 2000, pp 189-204.

Carpenter SR, Caraco NF, Corell DL, Howarth RW, Sharpley AN, Smith WH (1998) Nonpoint pollution of surface waters with phosphorus and nitrogen. Ecol Appl 8: 559-568.

Chevalier P, Proulx D, Lessard P, Vincent WF, Noüe J (2000) Nitrogen and phosphorus removal by high latitude mat-forming cyanobacteria for potential use in tertiary wastewater treatment. J Appl Phycol 12: 105-112.

Chinnasamy S, Bhatnagar A, Hunt RW, Das KC (2010) Microalgae cultivation in a wastewater dominated by carpet mill effluents for biofuel applications. Bioresource Technol 101: 3097-3105.

Chisti Y (2007) Biodiesel from microalgae. Biotechnol Adv 25: 294-306.

Christenson L, Sims R (2011) Production and harvesting of microalgae for wastewater treatment, biofuels and bioproducts. Biotechnol Adv 29: 686-702.

Craggs RJ, Adey WH, Jessup BK, Oswald WJ (1996). A controlled stream mesocosm for tertiary treatment of sewage. Ecol Eng 6: 149-169. 
Cromar NJ, Martin NJ, Christoff N, Read PA, Fallowfield HJ (1992) Determination of nitrogen and phosphorus partitioning within components of the biomass in a highrate algal pond: significance for the coastal environment of the treated effluent discharge. Water Sci Technol 25: 207-214.

Daniel TC, Sharpley AN, Edwards DR, Wedephl R, Lemunyon JL (1994) Minimizing surface water eutrophication from agriculture by phosphorus management. J Soil Water Conserv 49: 30-38.

Davison IR (1991) Environmental effects on algal photosynthesis. J Phycol 27: 2-8.

De Alva MS, Luna-Pabello VM, Cadena E, Ortíz E (2013) Green microalga Scenedesmus acutus grown on municipal wastewater to couple nutrient removal with lipid accumulation for biodiesel. Bioresource Technol 146: 744-748.

De-Bashan LE, Bashan Y (2004) Recent advances in removing phosphorus from wastewater and its future use as fertilizer. Water Res 38: 4222-4246.

De la Noüe J, Proulx D (1988) Biological tertiary treatment of urban wastewater with chitosan-immobilized Phormidium. Appl Microbiol Biotechnol 29: 292-297.

De la Noüe J, Laliberté G, Proulx D (1992) Algae and wastewater. J Appl Phycol 4: 247-254.

Doria E, Longoni P, Scibilia L, Iazzi N, Cella R, Nielsen E (2012). Isolation and characterization of a Scenedesmus acutus strain to be used for bioremediation of urban wastewater. J Appl Phycol 24: 375-383.

Erganshev AE, Tajiev SH (1986) Seasonal variations of phytoplankton numbers. Acta Hydrochim Hydrobiol 14: 613-625.

Edmondson WT (1970) Phosphorus, nitrogen and algae in Lake Washington after diversion of sewage. Science 169: 690-691.

Fallowfield HJ, Martin NJ, Cromar J (1999) Performance of a batch-fed high rate algal pond for animal waste treatment. Eur J Phycol 34: 231-237.

Fang J, Yuguang Z, Aiping P, Li N, Kibet R, Ying L, Renjie D (2015) Fed-batch cultivation of Desmodesmus sp. in anaerobic digestion wastewater for improved nutrient removal and biodiesel production. Bioresource Technol 184: 116-122.

Filip D, Peters VT (1979) Residual heavy metal removal by an algae-intermittent sand filtration system. Water Res 13: 305-313.

Filippino KC, Mulholand MR, Bott CB (2015) Phycoremediation strategies for rapid tertiary nutrient removal in a waste stream. Algal Res 11: 125-133.

Garcia J, Mujeriego R, Hernandéz-Mariné M (2000) High rate algal pond operating strategies for urban wastewater nitrogen removal. J Apl Phycol 12: 331-339.

Guzzon A, Bohn A, Diociaiuti M, Albertano P (2008) Cultured phototrophic biofilms for phosphorus removal in wastewater treatment. Water Res 42: 4357-4367.

Hemens J, Mason MH (1968) Sewage nutrient removal by a shallow algal stream. Water Res 2: 277-287.

Hoffman JP (1998) Wastewater treatment with suspended and nonsuspended algae. J Phycol 34: 757-763.

Holbrook GP, Davidson Z, Tatara RA, Ziemer NL, Rosentrater KA (2014) Use of the microalga Monoraphidium sp. grown in wastewater as a feedstock for biodiesel: Cultivation and fuel characteristics. Appl Energ 131: 386-393.

Holtan H (1981) Eutrophication of Lake Mjosa and its recovery. WHO Water Quality Bulletin 6: 99-156.

Howarth RW (1988) Nutrient limitation of net primary production in marine ecosystems. Annu Rev Ecol Syst 19: 898-910.

Hu Q, Sommerfeld M, Jarvis E, Ghirardi M, Posewitz M, Seibert M, Darzins A (2008) Microalgal triacylglycerols as feedstocks for biofuel production: perspectives and advances. Plant J 54: 621-639.

Humphrey KP, Stevensos RJ (1992) Responses of benthic algae to pulses in current and nutrients during simulations of subscouring spates. J N Am Benthol Soc 11: 37-48.

Hutchinson GE (1973) Eutrophication. Am Sci 61: 269-279.

Jarvie HP, Neal C, Warwick A, White J, Neal M, Wickham HD, Hill LK, Andrews MC (2002) Phosphorus uptake into algal biofilms in a lowland chalk river. Sci Total Environ 282-283: 353-373.

Jarvie HP, Sharpley AN, Withers PJA, Scott JT, Haggard BE, Neal C (2013) Phosphorus mitigation to control river eutrophication: murky waters, inconvenient truths and postnormal science. J Environ Qual 42: 295-304.

Jeppesen E, Jensen JP, Sondergaard M (2002) Response of phytoplankton, zooplankton and fish to re-oligotrophication: An 11year study of 23 Danish lakes. Aquat Ecosyst Health Manage 5: $31-43$.

Johnson M, Wen Z (2010) Development of an attached microalgal growth system for biofuel production. Appl Microbiol Biotechnol 85: 525-534.

Johnson RE, Tuchman NC, Peterson CG (1997) Changes in the vertical microdistribution of diatoms within a developing periphyton mat. J N Am Benthol Soc 16: 503-519.

Jones JR, Smart MM, Buroughs JN (1984) Factors related to algal biomass in Misouri Ozark streams. Verh Internat Verein Theor Angew Limnol 22: 1867-1875.

Kaya VM, Picard G (1996) Stability of chitosan gel as entrapment matrix of viable Scenedesmus bicellularis cells immobilized on screens for tertiary treatment wastewater. Bioresource Technol 56: $147-155$.

Kesaano M, Sims RC (2014) Algal biofilm based technology for wastewater treatment. Algal Res 5: 231-240.

Kangas P, Mulbry W (2013) Nutrient removal from agricultural drainage water using algal turf scrubbers and solar power. $\mathrm{Bi}$ oresource Technol 152: 484-489.

Kim J, Yoo G, Lee H, Lim J, Kim K, Kim CW (2013) Methods of downstream processing for the production of biodiesel from microalgae. Biotechnol Adv 31: 862-876.

Kim GY, Yun YM, Shin HS, Kim HS, Han JI (2015) Scenedesmus-based treatment of nitrogen and phosphorus effluent of anaerobic digester and bio-oil production. Bioresource Technol 196: $235-240$.

Komárek O, Sukačová K (2004) The use of artificial substrates in different growth conditions. Ekológia 2: 192-206.

Kroon BMA, Ketelaars HAM, Fallowfield HJ, Mur LR (1989) Modelling microalgal productivity in a high rate algal pond based on wavelenght dependent optical properties. Apl Phycol 1: 247-256.

Kumar V, Muthuraj M, Palabhanvi B, Das D (2016) Synchronized growth and neutral lipid accumulation in Chlorella sorokiniana FC6 IITG under continuous mode of operation. Bioresource Technol 200: 770-779.

Lardon L, Hélias A, Sialve B, Steyer J, Bernard O (2009) Life-cycle assesment of biodiesel production from microalgae. Environ Sci Technol 43: 6475-6481.

Lau PS, Tam NFY, Wong YS (1997) Wastewater nutrients (N and P) removal by carageenan and alginate immobilized Chlorella vulgaris. Environ Technol 18: 945-951.

Li T, Lin G, Podola B, Melkonian M (2015) Continuous removal of zinc from wastewater and mine dump leachate by a microalgal biofilm PSBR. J Hazard Mater 297: 112-118.

Liu T, Wang J, Hu Q, Cheng P, Ji B, Liu J, Chen Y, Zhang W, Chen X, Chen L, Gao L, Ji Ch, Wang H (2013) Attached cultivation 
technology of microalgae for efficient biomass feedstock production. Bioresource Technol 127: 216-222.

Liu J, Vyverman W (2015) Differences in nutrient uptake capacity of the benthic filamentous algae Cladophora sp., Klebsormidium sp. and Pseudanabaena sp. under varying N/P conditions. Bioresource Technol 179: 234-242.

Lowe RL, Golladay SW, Webster JR (1986) Periphyton response to nutrient manipulation in streams draining clearcut and forested watersheds. J N Am Benthol Soci 5: 221-229.

Mandal S, Mallick N (2009) Microalga Scenedesmus obliquus as a potential source for biodiesel production. Appl Microbiol Biotechnol 84: 281-291.

Mantzavinos D, Kalogerakis N (2005) Treatment of olive mill effluents: part I. Organic matter degradation by chemical and biological processes - an overview. Environ Int 31: 289-295.

Markou G, Nerantzis E (2013) Microalgae for high-value compounds and biofuels production: A review with focus on cultivation under stress conditions. Biotechnol Adv 31: 1532-1542.

Markou G, Georgakakis D (2011) Cultivation of filamentous cyanobacteria (blue-green algae) in agro-industrial wastes and wastewaters: A review. Appl Energ 88: 3389-3401.

Masojídek J, Prášil O (2010) The development of microalgal biotechnology in the Czech Republic. J Ind Microbiol Biotechnol 37: 1307-1317.

Mata TM, Martins AA, Caetano NS (2010) Microalgae for biodiesel production and other aplications: a review. Renew Sustain Energy Rev 14: 217-232.

Mehradabi A, Craggs R, Farid MM (2015) Wastewater treatment high rate algal ponds (WWT HRAP) for low cost biofuel production. Bioresource Technol 184: 202-214.

Metting B (1996) Biodiversity and application of microalgae. J Ind Microbiol 17: 477-489.

Metting B, Zimmerman WJ, Crouch I, Van Staden J (1990) Agronomic uses of seaweed and microalgae. In: Akatsuka I (ed) Introduction to Aplied Phycology. SPB Academic Publishing, The Hague, pp 589-627.

McCormick PV (1996) Resource competition and species coexistence in freshwater benthic algal assemblages. In: Stevenson RJ, Bothwell ML, Lowe RL (eds) Algal ecology: freshwater benthic ecosystems. Academic Press, San Diego, California, pp 229-252.

McIntire GD (1968) Structural characteristics of benthic algal communities in laboratory streams. Ecology 49: 520-537.

Mimouni V, Ulmann L, Pasquet V, Mathieu M, Picot L, Bougaran G, Cadoret JP, Morant-Manceau M, Schoefs B (2012) The potential of Microalgae for the Production of Bioactive Molecules of Pharmaceutical Interest. Curr Pharm Biotechnol 13: 1-17.

Mulholland PJ, Marzolf ER, Hendricks SP, Wilkerson RV, Baybayan AK (1995) Longitudinal patterns of nutrient cycling and periphyton characteristics in streams: test of upstream-downstream linkage. J N Am Benthol Soc 14: 357-370.

Mulholland PJ, Webster JR (2010) Nutrient dynamics in streams and the role of J-NABS. J N Am Benthol Soc 29: 100-117.

Mulbry W, Kondrad S, Pizarro C, Kebede-Westhead E (2008). Treatment of dairy manure effluent using freshwater algae: Algal productivity and recovery of manure nutrients using pilot-scale algal turf scrubbers. Bioresource Technology 99: 8137-8142.

Mulbry W, Westhead EK, Pizarro C, Sikora L (2005) Recycling of manure nutrients: use of algal biomass from dairy manure treatment as a slow release fertilizer. Bioresource Technol 96: 451-458.

Novotny V, Olem H (1994) Water quality: Prevention, Identification and Management of diffuse pollution, Van Nostrand Reinhold, New York.
Oswald WJ, Gotaas HB (1957) Photosynthesis in sewage treatment. Trans Am Soc Civ Eng 122: 73-105.

Palmer CM (1974) Algae in American sewage stabilization ponds. Rev Microbiol (S-Paulo) 5: 75-80.

Park JBK, Craggs RJ, Shilton AN (2011) Wastewater treatment high rate algal ponds for biofuel production. Bioresource Technol 102: 35-42.

Park JBK, Craggs RJ (2011) Algal production in wastewater treatment high rate algal ponds for potential biofuel use. Water Sci Technol 63: 2403-2410.

Park JBK, Craggs RJ, Shilton AN (2013) Enhancing biomass energy yield from pilot-scale high rate algal ponds with recycling. Water Res 47: 4422-4432.

Picot B, El Halouani H, Casella C, Moersidik S, Bontoux J (1991) Nutrient removal by high rate pond system in a meditaranesn climate (France). Water Sci Technol 23: 1535-1541.

Pittman JK, Dean AP, Osundeko O (2011). The potential of sustainable algal biofuel production using wastewater resources. Bioresource Technol 102: 17-25.

Posadas E, García-Encina PA, Soltau A, Domínguez A, Díaz I (2013) Carbon and nutrient removal from centrates and domestic wastewater using algal-bacterial biofilm bioreactors. $\mathrm{Bi}$ oresource Technol 139: 50-58.

Proulx D, Lessard P, de la Noüe J (1994) Traitement tertaire d'un effluent domestique secondaire par culture intensive de la cyanobactérie Phormidium bohneri. Environmental Technol 15: 449-458.

Quinn JM (1991) Guidelines for the control of undesireable biological growths in water (Consultancy report No 6213/2). Water Quality Centre, Hamilton, New Zealand.

Rawat I, Kumar RR, Mutanda T, Bux F (2011) Dual role of microalgae: Phycoremediation of domestic wastewater and biomass production for sustainable biofuels production. Appl Energ 88: 3411-3424.

Reckhow KH (1988) Empirical models for trophic state in southeastern US lakes and reservoirs. Water Resour Bull 24: 723-734.

Ren HY, Liu BF, Kong F, Zhao L, Ren N (2015) Hydrogen and lipid production from starch wastewater by co-culture of anaerobic sludge and oleaginous microalgae with simultaneous COD, nitrogen and phosphorus removal. Water Res 85: 404-412.

Renuka N, Sood A, Ratha SK, Prasanna R, Ahluwalia AS (2013) Evaluation of microalgal consortia for treatment of primary treated sewage effluent and biomass production. J Appl Phycol 25: 1529-1537.

Roberts DA, Paul NA, Cole AJ, de Nys R (2015) From wastewater treatment to land management: Conversion of aquatic biomass to biochar for soil amelioration and the fortification of crops with essential trace elements. J Environ Manag 157: 60-68.

Sandefur HN, Matlock MD, Costello TA (2011) Seasonal productivity of a periphytic algal community for biofuel feedstock generation and nutrient treatment. Ecol Eng 37:1476-1480.

Schindler DW (1977) Evolution of phosphorus limitation in lakes. Science 195: 260-262.

Schindler DW (2006) Recent advances in the understanding and management of eutrophication. Limnol Oceanogr 5: 356-363.

Scholz RW, Ulrich AE, Eilittä M, Roy A (2013) Sustainable use of phosphorus: A finite resource. Sci Total Environ 461-462: 799-803.

Shelef G, Soeder CJ (1980) Algal biomass: production and use. Elsevier Press. Amsterdam.

Shi J, Podola B, Melkonian M (2014) Application of a prototype-scale Twin-Layer photobioreactor for effective $\mathrm{N}$ and $\mathrm{P}$ removal from different process stages of municipal wastewater by immobilized microalgae. Bioresource Technol 154: 260-266. 
Sim TS, Goh A (1988) Ecology of microalgae in a high rate pond for piggery effluent purification in Singapore. MIRCEN J Appl Microb 4:285-297.

Skulberg OM, Codd GA, Carmichael WW (1984) Toxic bluegreen algal blooms in Europe: a growing problem. Ambio 13: 244-247.

Sládečková A, Marvan P, Vymazal J (1983) The utilization of perifyton in waterworks pre-treatment for nutrient removal from enriched influents. Develop Hydrobiol 17: 299-303.

Sládečková A (1962) Limnological investigation methods for the periphyton (Aufurichs) community. Bot Rev 28: 286-350.

Smith VH, Joye SB, Howarth RW (2006) Eutrophication of freshwater and marime ecosystems. Limnol Oceanogr 51: 351-355.

Smith VH (1998) Cultural eutrophication of inland, estuarine, and coastal waters. In: Pace ML, Grofmann PM (eds) Successes, limitations and frontiers in ecosystem science. Springer, pp 7-49.

Spolaore P, Joannis-Cassan C, Duran E, Isambert A (2006) Commercial Applications of Microalgae. J Biosci Bioeng 101: 87-96.

Stanier RY, Kunisawa R, Mandel M, Cohen-Bazire G (1971) Purification and properties of unicellular blue-green algae (Order Chroococcales). Bacteriol Rev 35: 171-205.

Stevenson RJ, Bothwell ML, Lowe RL (eds) (1996) Algal Ecology. Freshwater Benthic Ecosystems. Elsevier Inc, USA, pp 1-753.

Subaschandrabose SR, Ramakrishnan B, Megharaj M, Venkateswarlu K, Naidu R (2011) Consortia of cyanobacteria/microalgae and bacteria: Biotechnological potential. Biotechnol Adv 29: 896-907.

Sukačová K, Trtílek M, Rataj T (2015) Phosphorus removal using a microalgal biofilm in a new biofilm photobioreactor for tertiary wastewater treatment. Water Res 71: 55-63.

Sukenik A, Levy RS, Levy Y, Falkowski PG, Dubinsky Z (1991) Optimizing algal biomass production in an outdoor pond: a simulation model. J Appl Phycol 3: 191-203.

Talbot P, de la Noüe J (1993) Tertiary treatment of wastewater with Phormidium bohneri (Schmidle) under various light and temperature conditions. Water Res 27: 153-159.

Valeta J, Verdegem M (2015) Removal of nitrogen by Algal Turf Scrubber Technology in recirculating aquaculture systém. Aquac Res 46: 945-951.
Van Dijk KC, Lesschen JP, Oenema O (2016) Phosphorus flows and balances of the European Union Member States. Sci Total Environ 542: 1078-1093.

Vollenweider RA (1968) Scientific fundamentals of the eutrophication of lakes and flowing waters, with particular reference to nitrogen and phosphorus as factors in eutrophication. Technical Report. OECD.

Vymazal J (1988) The use of periphyton communities for nutrient removal from polluted streams. Hydrobiologia 166: 225-237.

Wang B, Lan CQ (2011) Biomass production and nitrogen and phosphorus removal by the green alga Neochloris oleoabundans in simulated wastewater and secondary municipal wastewater effluent. Bioresource Technol 102: 5639-5644.

Weber CA (1907) Aufbau und Vegetation der Moore Norddeutschlands. Beibl Bot Jahrb 90: 19-34.

Wehr JD, Sheath RG, Kociolek JP (2015) Freshwater algae of North America. Ecology and Classification. Academic Press, USA, pp $1-1025$.

Wei Q, Hu Z, Li G, Xiao B, Sun H, Tao M (2008) Removing nitrogen and phosphorus from simulated wastewater using algal biofilm technique. Front Environ Sci Engin China 2: 446-451.

Wetzel RG (2001) Limnology: Lake and River Ecosystems. Academic Press.

Wilde EW, Benemann JR (1993) Bioremoval of heavy metals by the use of microalgae. Biotechnol Adv 11: 781-812.

Whitford LA, Schumacher GJ (1961) Effect of current on mineral uptake and respiration by a freshwater alga. Limnol Oceanogr 6: $423-425$

Whitton R, Ometto F, Pidou M, Jarvis P, Villa R, Jefferson B (2015) Microalgae for municipal wastewater nutrient remediation: mechanisms, reactors and outlook for tertiary treatment. Environ Technol Rev. doi:10.1080/21622515.2015.1105308.

Zhang E, Wang B, Wang Q, Zhang S, Zhao B (2008) Ammonia-nitrogen and orthophosphate removal by immobilized Scenedesmus sp. isolated from municipal wastewater for potential use in tertiary treatment. Bioresource Technol 99: 3787-3793.

Zippel B, Rijstenbil J, Neu TR (2007) A flow-lane incubator for studying freshwater and marine phototrophic biofilms. J Microbiol Methods 70: 336-345. 